\title{
Anti-edema effect of melatonin on spinal cord injury in rats
}

\author{
Xinwei Liü ${ }^{\mathrm{a}}$, Yu Wang ${ }^{\mathrm{a}}$, , Jishun Yang ${ }^{\mathrm{b}}$, Yunen Liuc, Dapeng Zhou ${ }^{\mathrm{a}}$, Mingxiao Houc, Liangbi Xiang ${ }^{\mathrm{a}}$
}

\begin{abstract}
Aim. To determine the anti-edema effects of melatonin on spinal cord injury (SCI) in rats.
Methods. A total of 150 adult male Sprague-Dawley rats were randomly allocated to the following three groups $(n=50)$ : a sham group which underwent laminectomy without dural compression; an $\mathrm{SCl}$ group, which underwent laminectomy followed by SCl and received saline i.p. immediately after injury and then daily for 2 days; an MT group, which underwent laminectomy followed by $\mathrm{SCl}$ and received a $100 \mathrm{mg} / \mathrm{kg}$ dose of melatonin i.p. immediately after $\mathrm{SCl}$ and then daily for 2 days. The cords were removed at 12, 24, 48 and $72 \mathrm{~h}$ after surgery in every group. Spinal cord edema was evaluated by determining the spinal cord water content. Expressions of AQP4 and GFAP positive cells in injured spinal cord were detected by immunohistochemical staining, and protein expressions of AQP4 and GFAP were detected by Western blotting.

Results. Spinal cord water content was obviously increased after SCl, which was maintained almost unchanged by melatonin treatment $(100 \mathrm{mg} / \mathrm{kg}$ ) at $12 \mathrm{~h}$ after injury but was significantly reduced from $24 \mathrm{~h}$ to $72 \mathrm{~h}$. The expressions of AQP4 and GFAP increased in the injured spinal cord segments, which were decreased by melatonin treatment (100 $\mathrm{mg} / \mathrm{kg}$ ) between $24 \mathrm{~h}$ and $72 \mathrm{~h}$ after $\mathrm{SCl}$.

Conclusions. Melatonin ( $100 \mathrm{mg} / \mathrm{kg}$ ) had anti-edema effects after acute SCI probably by down-regulating the expression level of AQP4 protein, and it may eliminate astrocytic swelling after SCI through down-regulating the expression level of GFAP protein.
\end{abstract}

Key words: edema, melatonin, spinal cord injury, rats

Received: August 17, 2014; Accepted: March 10, 2015; Available online: April 24, 2015

http://dx.doi.org/10.5507/bp.2015.012

${ }^{a}$ Department of Orthopedics, General Hospital of Shenyang Military Area Command of Chinese PLA, Rescue Center of Severe Wound and Trauma of Chinese PLA, Shenyang 110016, China

'The Medical Department, No. 100 Hospital of Chinese PLA, Suzhou 215007, China

'Department of Emergency, General Hospital of Shenyang Military Area Command of Chinese PLA, Rescue Center of Severe Wound and Trauma of Chinese PLA, Shenyang 110016, China

"These authors contributed equally to the work.

Corresponding author:Liang-Bi Xiang, e-mail:xiangliangbido@163.com

\section{INTRODUCTION}

The annual incidence of spinal cord injury (SCI) is 11.5-53.4 cases/million population worldwide. It impairs motor, sensory and autonomic functions ${ }^{1-3}$. The degree of dysfunction having direct effects on the the quality of life of the affiliated. For this reason, regenerating injured spinal cords is attractive in both clinical and basic medical research fields. As a complex cytological and biological process, repair of the spinal cord remains problematic. SCI is associated with spinal cord edema that readily leads to morbidity and mortality ${ }^{4,5}$ and adversely affects the postoperative outcome. For this reason, mitigating spinal cord edema ${ }^{6}$ would have a beneficial effect on the SCI ( ref. $\left.^{7}\right)$.

There are currently no specific drugs for SCI treatment. Despite many studies, neurological dysfunction that occurs at or below the level of the neurological insult can only be treated by the administration of methylprednisolone (MP) within $8 \mathrm{~h}$ after injury ${ }^{8-12}$. However, MP has side-effects that make its use in clinical practice controversial. On the other hand, Melatonin (N-acetyl-5methoxytryptamine), which is the main secretory product of the pineal gland that functions as a biological synchronizer in the circadian rhythm, has high antioxidant activities $^{13-18}$.

Aquaporins play important roles in water transport in many types of cells. Aquaporin-4 (AQP4) protein is highly expressed in the central nervous system (CNS) $\left(\right.$ ref. ${ }^{19,20}$ ), the expression changes of which are associated with spinal cord edema and the permeability of bloodspinal cord barrier ${ }^{21,22}$. The expression of AQP4 in injured spinal cords changes in a similar manner to the water content of spinal $\operatorname{cord}^{23,24}$. The swelling of astrocytes for which GFAP is a specific marker also plays a crucial role in cellular edema after acute SCI.

The effect of melatonin on spinal cord edema after SCI remains unknown to date. The aim of this study was to investigate the anti-edema effects of melatonin $(100 \mathrm{mg} / \mathrm{kg}$ ) on spinal cord edema after acute SCI and its underlying mechanism. 


\section{MATERIALS AND METHODS}

\section{Animals and surgical technique}

After acceptance of the local ethics committee, the study was started at the Severe Wound and Trauma Laboratory of General Hospital of Shenyang Military Area Command of Chinese PLA. Efforts were made to minimize animal suffering and to reduce the number of animals used in experimental groups. Adult male Sprague-Dawley (SD) rats (205-225 g) were used for the study protocol. The animals were housed in cages (4 per cage) before surgery. Water and food were continuously available during preoperative and postoperative periods. Twelve-hour daylight and darkness cycles were used before and after surgery. Room temperature was kept constant $(26 \pm 2)^{\circ} \mathrm{C}$.

Rats were anesthetized with chloral hydrate $(300 \mathrm{mg} /$ $\mathrm{kg}$ body weight). Breathing was continued spontaneously with room air. The animals were supine on the operating table. Under sterile conditions, a midline dorsal incision was made and laminectomy was performed at the T12level vertebra, leaving the dura intact. Strict bleeding control was held by using bone wax and bipolar coagulator. An aneurysm clip was applied extradurally for $5 \mathrm{~min}$ on thoracic spinal cord at room temperature. After careful removal of the clip, paravertebral fascia and skin were sutured separately with silk stitches. A complete closure of surgical wound was achieved. Complicated cases, such as dural tearing or inadvertent spinal injuries, were excluded from the study. Rats were examined in the early postoperative period and settled in cages separately. Food and water were provided. The urinary bladders were pressed three times a day.

\section{Experimental groups}

A total of 150 rats were randomly allocated to the following three groups $(n=50)$ : Sham group, which underwent laminectomy alone, without dural compression; SCI group, which underwent laminectomy followed by SCI and received saline i.p. immediately after injury and then daily for 2 days; MT group, which underwent laminectomy followed by SCI and received a $100 \mathrm{mg} / \mathrm{kg}$ dose of melatonin (Hangzhou Gosun Biotechnologies Co., Ltd., China) i.p. immediately after SCI and then daily for 2 days. Melatonin was dissolved in ethanol and further diluted in physiological saline. The final ethanol concentration was $5 \%$. At $12,24,48$ and $72 \mathrm{~h}$ following trauma, five rats from each group were used for analysis of the spinal cord water content, and another five for Western blot analysis, respectively. At 24 and $72 \mathrm{~h}$ after operation, five rats from each group were used for immunohistochemical (IHC) staining.

\section{Determination of spinal cord water content}

Spinal cord edema was evaluated by determining the spinal cord water content. The cords were removed at 12 , 24,48 and $72 \mathrm{~h}$ after surgery in each group. The spinal cords were $1 \mathrm{~cm}$ long segments centered at the injury epicenter. After determination of the wet weight, the injured spinal cords were dried for $48 \mathrm{~h}$ at $80{ }^{\circ} \mathrm{C}$ to determine the dry weight. Water content in spinal cord tissue was calculated as (wet weight - dry weight)/ wet weight $\times 100 \%$.

\section{IHC staining}

IHC staining was performed, to investigate the expressions of the AQP4 and GFAP positive cells in the injured spinal cord at 24 and $72 \mathrm{~h}$ after injury. To remove the cords, animals were reanesthetized and perfused transcardially with saline followed by $4 \%$ paraformaldehyde in phosphate buffered saline (0.1 M PBS, pH 7.4). Then the cords were further exposed from vertebrae T10 to L1 so that $1 \mathrm{~cm}$ long segments centered at the injury site were removed and fixed in the same fixative for another $24 \mathrm{~h}$ at $4{ }^{\circ} \mathrm{C}$. The fixed cords were dehydrated and embedded in paraffin sections. Axial tissue sections $(10 \mu \mathrm{m})$ were cut with a microtome at $3 \mathrm{~mm}$ upper of the SCI epicenter. Sections were deparaffinized and treated with $3 \% \mathrm{H}_{2} \mathrm{O}_{2}$ for $15 \mathrm{~min}$ to block endogenous peroxidase. The sections were exposed to normal goat serum for $30 \mathrm{~min}$, and then incubated with the following primary antibodies overnight at $4^{\circ} \mathrm{C}$ : rabbit polyclonal anti-AQP4 antibody (diluted 1:150, Santa Cruz Biotechnology, Inc.) or mouse monoclonal anti-GFAP antibody (diluted 1:400, Sigma). After washing in PBS, the sections were incubated with the appropriate secondary antibody (ZSGB-BIO, China) at 37 ${ }^{\circ} \mathrm{C}$ for $15 \mathrm{~min}$. Immunolabelling was visualized as brown, using diaminobenzidine, with hematoxylin counterstain. The number of AQP4 or GFAP positive cells in the gray matter of the sections was counted in a rectangular area of $190 \times 340 \mu \mathrm{m}^{2}$ by two observers (unaware of the experimental groups). The results counted by two observers were averaged to obtain the final count for the section.

\section{Western blot}

Western blot analysis was carried out to investigate the protein expressions of AQP4 and GFAP in the injured spinal cords at 12, 24, 48 and $72 \mathrm{~h}$ after injury. Spinal cord samples were $1 \mathrm{~cm}$ long and were homogenized in RIPA buffer. After homogenization, the samples were centrifuged at $17,000 \mathrm{~g}$ for $15 \mathrm{~min}$ at $4{ }^{\circ} \mathrm{C}$. The protein concentration of soluble materials was determined by the Coomassie G250 Binding method. The protein lysates were fractioned on $12 \%$ SDS-polyacrylamide gels, followed by transfer to PVDF membranes. The membranes were blocked with $5 \%$ skimmed milk for $2 \mathrm{~h}$ and then incubated with primary polyclonal antibody anti-AQP4 (dilution 1:400, Santa Cruz Biotechnology, Inc.), GFAP (dilution 1:200, Sigma) or $\beta$-actin (dilution 1:2000, Santa Cruz Biotechnology, Inc.) overnight at $4{ }^{\circ} \mathrm{C}$, followed by corresponding second antibody for $2 \mathrm{~h}$ at room temperature. The EC3 Imaging System (UVP Inc. Upland, CA, USA) was used to catch up the AQP4, GFAP protein bands and $\beta$-actin bands, and the optical density of every band was measured using an Image $\mathbf{J}$ software (NIH, Bethesda, MD, USA). To determine the expression levels of AQP4 and GFAP, the value of the protein was normalized to the corresponding $\beta$-actin band. 


\section{Statistical analysis}

SPSS 16.0 software was used for the statistical analysis. Data presented as Means \pm SD. One-way analysis of variance was performed to determine the differences among the groups for spinal cord water content, AQP4 and GFAP level. A p-value less than 0.05 was considered statistically significant.

\section{RESULTS}

\section{Effects of melatonin on spinal cord water content}

The spinal cord water content is shown in Fig. 1. The spinal cord water content after injury was significantly increased in the SCI group compared with that of Sham group at 12, 24, 48 and $72 \mathrm{~h}$ after injury. The spinal cord water content after injury was significantly reduced in the melatonin group compared with that of SCI group at 24, 48 and $72 \mathrm{~h}$ after injury, whereas it did not change significantly at $12 \mathrm{~h}$ after injury.

\section{Effect of melatonin on AQP4 expression}

The expression of AQP4 was detected using IHC and Western blot methods. The IHC results of AQP4 are shown in Fig. 2. AQP4 positive cells were strongly expressed in gray matter, around capillaries and in radial astrocytes. The number of AQP4 positive cells in the SCI group significantly exceeded that of the Sham group at 24 and $72 \mathrm{~h}$ after injury $(P<0.05)$. In the MT group, the number of AQP4 positive cells was significantly downregulated at 24 and $72 \mathrm{~h}$ after injury compared with that of SCI group $(P<0.05)$.

The representative Western blot gels for AQP4 (34 $\mathrm{kDa})$ and $\beta$-actin (42 kDa) are shown in Fig. 3. The

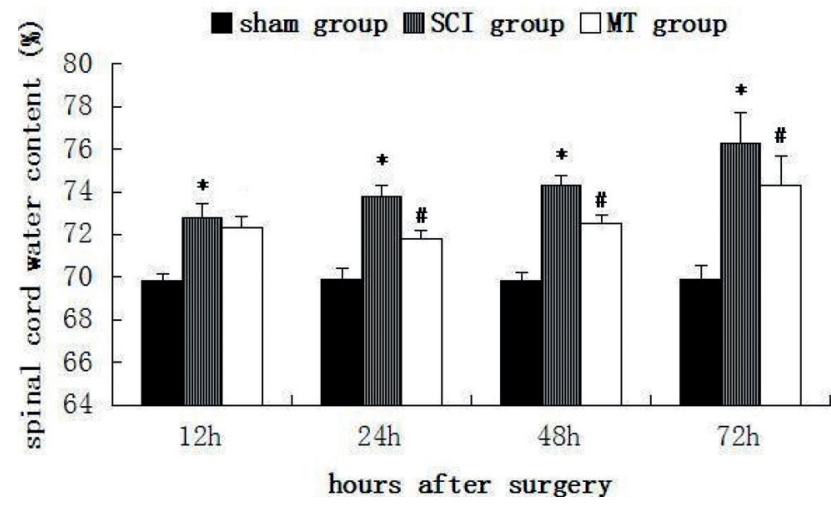

Fig. 1. Spinal cord water contents at 12, 24, 48 and $72 \mathrm{~h}$ after injury. The figure shows a significant increase in the spinal cord water content in SCI group compared with that of Sham group at 12, 24, 48 and $72 \mathrm{~h}$ after injury, while a significant reduction was observed in MT group compared with that of SCI group at 24,48 and $72 \mathrm{~h}$ after injury. Data present mean \pm SD ( $\mathrm{n}=5$, $* P<0.05$ between Sham group and SCI group, $\# P<0.05$ between MT group and SCI group). level of AQP4 was quantified and normalized to $\beta$-actin. AQP4 was expressed at low level in the Sham group and significantly increased at 12, 24, 48 and 72 hs after injury $(P<0.05$, Fig. 3A-D). The level of AQP4 in the melatonin group plummeted compared with that of SCI group at 24, 48 and 72 hs after injury ( $P<0.05$, Fig. 3B-D) but 12 hs after injury, there were no significant differences between the SCI and MT groups ( $P>0.05$, Fig. 3A).

\section{Effect of melatonin on GFAP expression}

The IHC results of GFAP are shown in Fig. 4. The number of GFAP positive cells was significantly increased in the SCI group compared with that of Sham group at 24 and 72 hrs after injury $(P<0.05)$. In the MT group, the number of GFAP positive cells was obviously decreased at 24 and 72 hrs after injury compared with that of SCI group $(P<0.05)$.

With Western blot analysis, the IDVs of GFAP compared with $\beta$ - actin are shown in Fig. 3. GFAP level was low in the Sham group and significantly increased at 12, 24, 48 and $72 \mathrm{~h}$ after injury $(P<0.05$, Fig. 3A-D). Compared with SCI group, the expression level of GFAP protein in MT group obviously dropped at 24, 48 and $72 \mathrm{~h}$ after injury $(P<0.05$, Fig. 3B-D). There were no
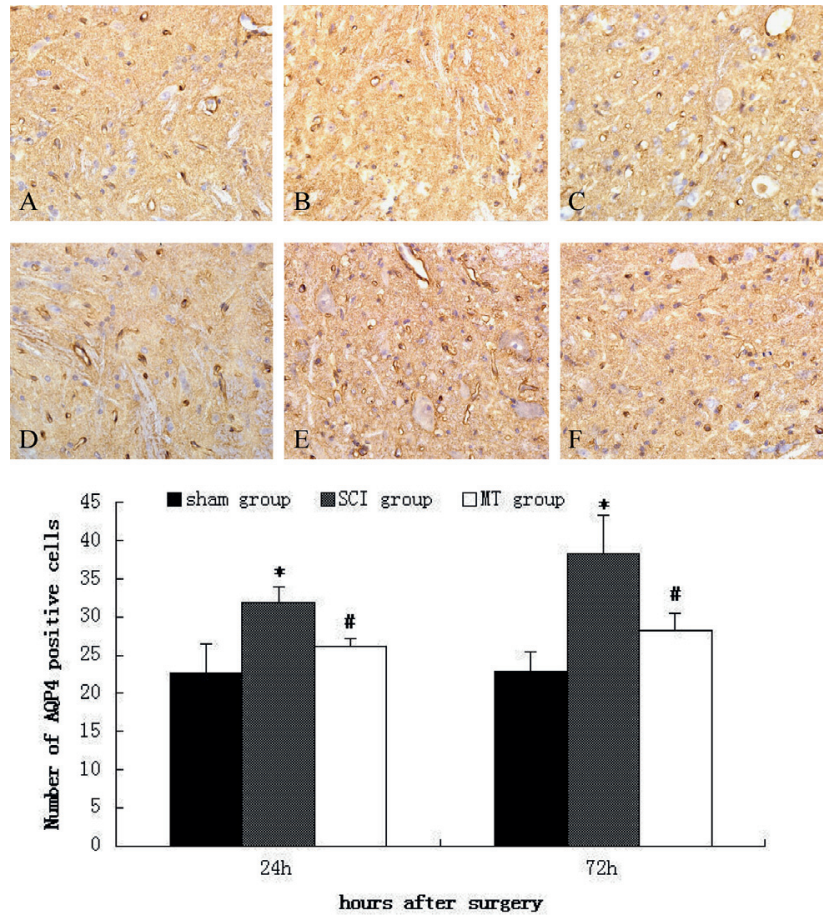

Fig. 2. Changes of AQP4 positive cells expression by IHC method at 24 and $72 \mathrm{~h}$ after injury (A: $24 \mathrm{~h}$ of Sham group, B: $24 \mathrm{~h}$ of SCI group, C: $24 \mathrm{~h}$ of MT group, D: $72 \mathrm{~h}$ of Sham group, E: $72 \mathrm{~h}$ of SCI group, and F: $72 \mathrm{~h}$ of MT group). The number of AQP4 positive cells in gray matter regions in SCI group was significantly up-regulated compared with that in Sham group at 24 and $72 \mathrm{~h}$ after injury. The number of AQP4 positive cells in MT group was significantly down-regulated compared with that in SCI group at 24 and $72 \mathrm{~h}$ after injury. Data present mean $\pm \mathrm{SD}(\mathrm{n}=5, * P<0.05$ between Sham group and SCI group, $\# P<0.05$ between MT group and SCI group, Scale bar=50 $\mu \mathrm{m}$ ). 


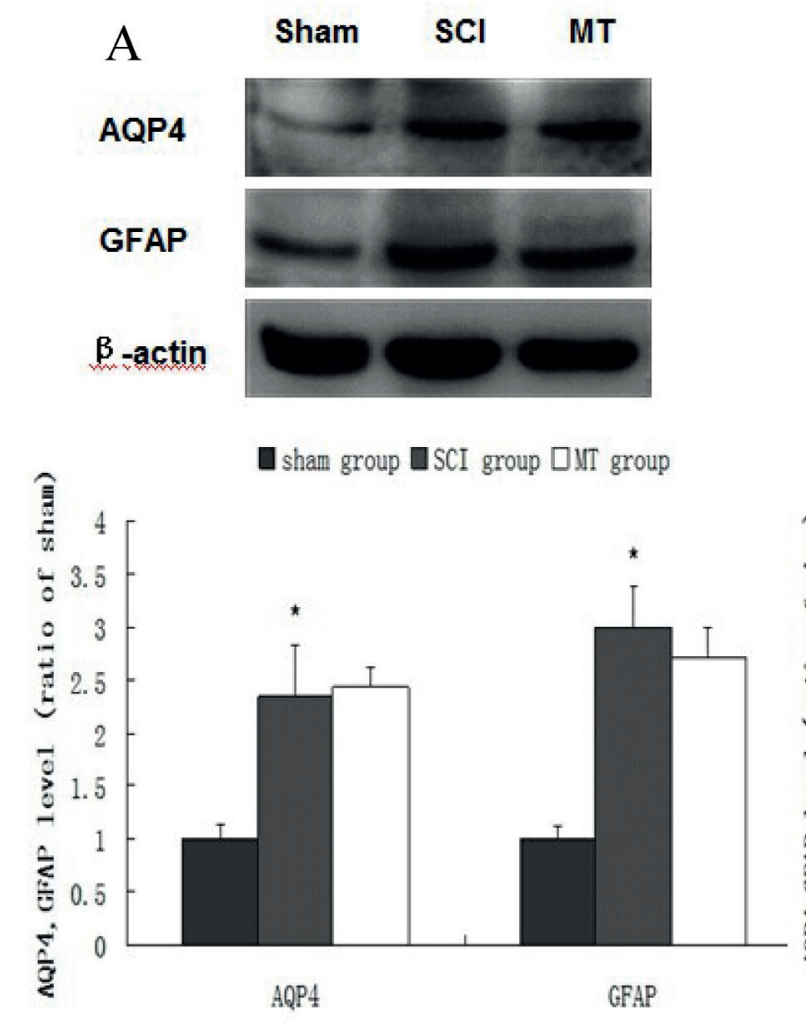

B

AQP4

Sham $\quad \mathrm{SCl} \quad \mathrm{MT}$

GFAP
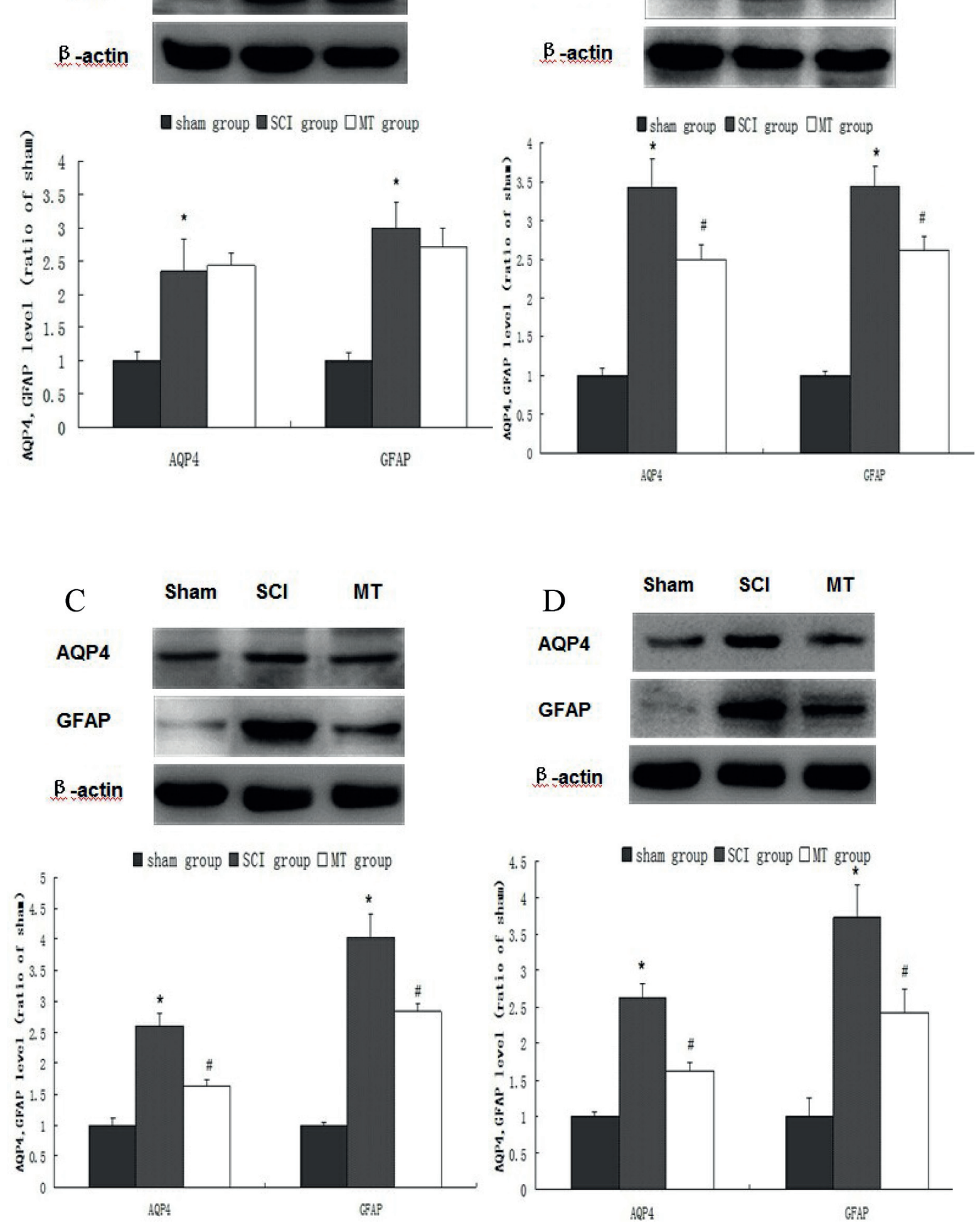

Fig. 3. Western blot analysis for AQP4 and GFAP protein levels at 12 (A), 24 (B), 48 (C) and 72 h (D) after injury. AQP4 was detected at $34 \mathrm{kDa}$, GFAP was detected at $50 \mathrm{kDa}$ and the loading control $\beta$-actin at $43 \mathrm{kDa}$. The graph showed significantly upregulation of AQP4 and GFAP expression level in SCI group at 12, 24, 48 and $72 \mathrm{~h}$ after SCI. Treatment of melatonin (100 mg/ $\mathrm{kg}$ ) could markedly decrease AQP4 and GFAP levels in the spinal cord at 24, 48 and $72 \mathrm{~h}$ after injury. There were no significant differences in AQP4 and GFAP protein levels between SCI group and melatonin group at $12 \mathrm{~h}$ post-injury. Bars represent mean $\pm \mathrm{SD}(\mathrm{n}=5, * P<0.05$ between Sham group and SCI group, $\# P<0.05$ between SCI group and melatonin group). 

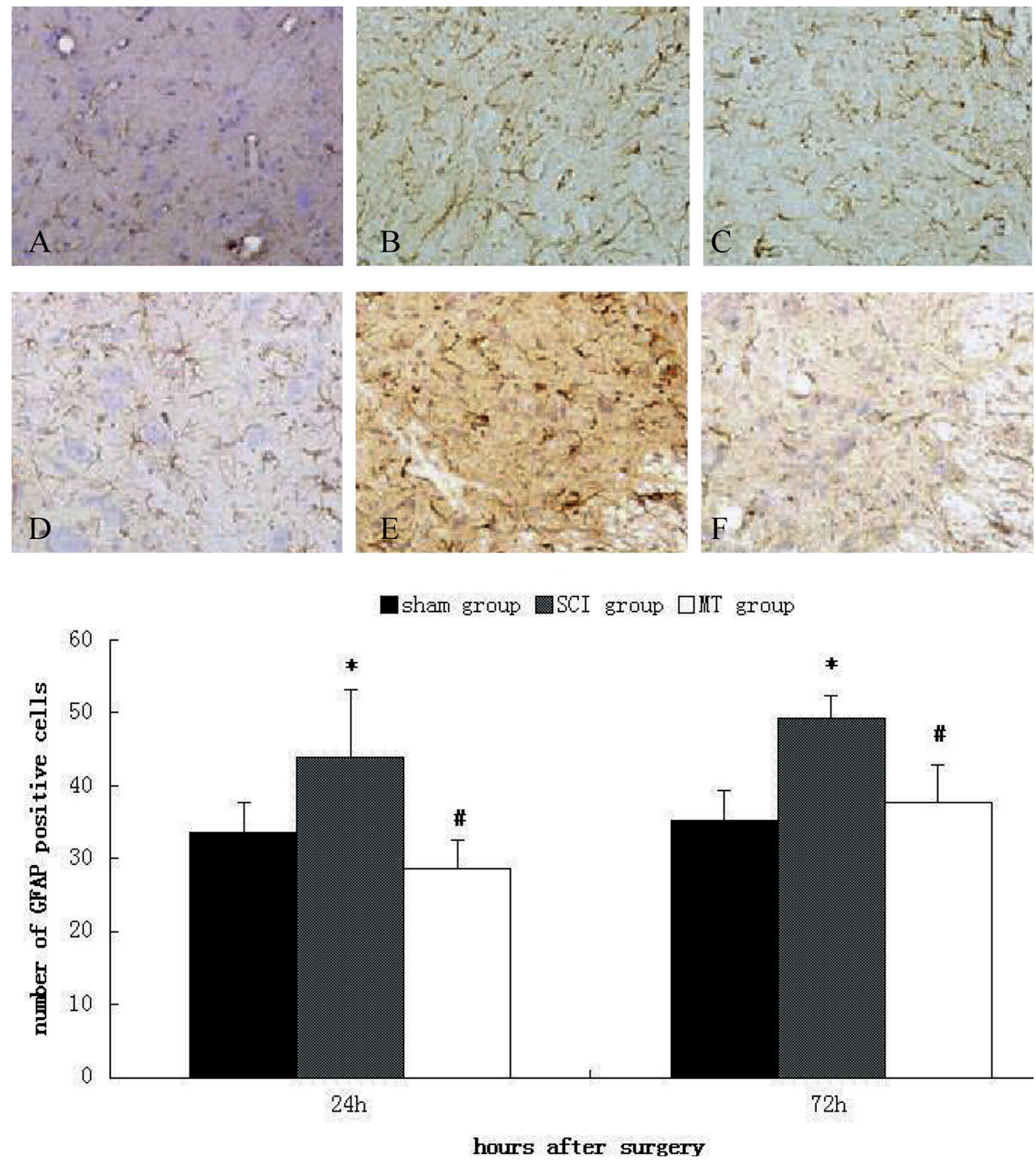

Fig. 4. Changes of GFAP positive cells expression using IHC method at 24 and $72 \mathrm{~h}$ after injury (A: $24 \mathrm{~h}$ of Sham group, B: $24 \mathrm{~h}$ of SCI group, C: $24 \mathrm{~h}$ of MT group, D: $72 \mathrm{~h}$ of Sham group, E: $72 \mathrm{~h}$ of SCI group, and F: $72 \mathrm{~h}$ of MT group). The number of GFAP positive cells in gray matter regions in SCI group was significantly up-regulated compared with that of Sham group at 24 and $72 \mathrm{~h}$ after injury. The number of GFAP positive cells in MT group was significantly down-regulated compared with that of SCI group at 24 and $72 \mathrm{~h}$ after injury. Data present mean $\pm \mathrm{SD}(\mathrm{n}=5, * P<0.05$ between Sham group and SCI group, $\# P<0.05$ between melatonin group and SCI group, scale bar $=50 \mu \mathrm{m}$ ).

significant differences between the SCI group and MT group at 12 hs after injury $(P>0.05$, Fig. $3 \mathrm{~A})$.

\section{DISCUSSION}

In previous studies, SCI has been effectively treated with 50 or $100 \mathrm{mg} / \mathrm{kg}$ melatonin ${ }^{25-27}$. Gül et al. reported the neuroprotective effects of melatonin on experimental SCI in rats ${ }^{28}$. The $100 \mathrm{mg} / \mathrm{kg}$ group had better outcomes than the $50 \mathrm{mg} / \mathrm{kg}$ group did. Therefore, we chose 100 $\mathrm{mg} / \mathrm{kg}$ melatonin to treat SCI.

Two foremost studies have shown the highly beneficial effects of melatonin on experimental SCI (ref. ${ }^{29,30}$ ). Both studies used similar weight drop injury models, with the first $50 \mathrm{~g} / \mathrm{cm}$ and and the other $25 \mathrm{~g}$ per $10 \mathrm{~min}$. However, dose regimens were significantly different in these studies: 100 and $2.5 \mathrm{mg} / \mathrm{kg}$. The first study concluded that melatonin had significant protective effects mainly on myelin sheaths but also on nucleus and mitochondria. Similarly, the other study suggested that melatonin could protect against oxidative damage and reduce neutrophil-induced toxicity.

This study demonstrated that melatonin $(100 \mathrm{mg} /$ $\mathrm{kg}$ ) treatment exerted good therapeutic effects following SCI, managing to decrease the spinal cord water content, AQP4 level and GFAP level.

SCI can result in serious disability, sensory disorders, paralysis, other neurologic deficits, and death ${ }^{31}$. To this end, it is necessary to understand the pathophysiology of the acute phase following SCI and to develop effective therapeutic interventions. Commonly, $\mathrm{SCI}$ is initiated by a 
primary injury that causes mechanical compression of the spinal cord, followed by a secondary injury that induces considerable apoptotic cell death ${ }^{32}$. Secondary damage after SCI includes edema, altered blood flow, and changes in microvascular permeability ${ }^{33,34}$. Traumatic injury to the spinal cord is often associated with edema that is predominant in the gray matter ${ }^{19,35}$. This progressive, active spread of damage begins within minutes after initial injury and continues for weeks ${ }^{36}$. In this study, we used the rat model of SCI to examine the protective effects of melatonin (100 $\mathrm{mg} / \mathrm{kg}$ ) on spinal cord edema from 12 to $72 \mathrm{~h}$ after SCI.

The spinal cord water content was obviously increased after SCI, which was maintained almost unchanged by melatonin treatment $(100 \mathrm{mg} / \mathrm{kg})$ at $12 \mathrm{~h}$ after injury but was significantly reduced from $24 \mathrm{hrs}$ to $72 \mathrm{hrs}$. Therefore, melatonin effectively reduced SCI-induced spinal cord edema after a latency period and for the duration of the observation. As we described before, the pathophysiology of SCI comprises primary and secondary damage. Primary damage includes microvascular bleeding that also increases the spinal cord water content. The increase of spinal cord water content at $12 \mathrm{~h}$ after SCI may be ascribed to both primary and secondary damage, and melatonin treatment was unable to mitigate primary damage. The therapeutic effects of melatonin are mainly on the secondary damage.

We used IHC and Western blot methods to describe the expression levels of AQP4 and GFAP proteins after SCI. AQP4, as a member of the AQP family, is widely expressed in the nervous system. Previous studies showed the colocalization of AQP4 with GFAP in double labeling by using confocal microscopy ${ }^{37,38}$. Badaut et al. reported that AQP4 was found in astrocyte foot processes around capillaries in the human brain ${ }^{39}$. Oshio et al. found that AQP4 was intensely stained throughout the gray matter in spinal cord, especially in the capillary-surrounding astrocytic end-feet ${ }^{19}$. In particular, AQP4 and spinal cord edema are positively correlated ${ }^{40,41}$. AQP4 in spinal cord is expressed in glial cells throughout the gray matter and glial foot processes adjacent to the spinal capillary endothelium ${ }^{19}$. In this study, AQP4 expression was significantly increased from 24 to $72 \mathrm{~h}$ after SCI, which was obviously decreased by melatonin treatment (100 $\mathrm{mg} / \mathrm{kg})$. Accordingly, melatonin (100 mg/kg) may exert anti-edema effects from 24 to $72 \mathrm{~h}$ after SCI by decreasing the AQP4 level. Conceivably, down-regulating AQP4 expression by melatonin $(100 \mathrm{mg} / \mathrm{kg})$ treatment may be conducive to alleviating the spinal cord edema in SCI rats.

Liang et al. demonstrated that cellular edema was important after CNS injury. Astrocytes are much more prone to swelling than neurons ${ }^{42}$, for which GFAP is a specific marker ${ }^{43}$. In this study, melatonin $(100 \mathrm{mg} / \mathrm{kg})$ could obviously decrease the GFAP protein level in the spinal cord from 24 to $72 \mathrm{~h}$ after SCI. This may play a role in eliminating astrocytic swelling after SCI. In conclusion, the expressions of AQP4 and GFAP increased in the injured spinal cord segments. Melatonin treatment (100 $\mathrm{mg} / \mathrm{kg}$ ) decreased AQP4 and GFAP levels in spinal cord segments between $24 \mathrm{~h}$ and $72 \mathrm{~h}$ after SCI, implying that melatonin $(100 \mathrm{mg} / \mathrm{kg})$ had anti-edema effects after acute
SCI probably by down-regulating the expression level of AQP4 protein. Furthermore, melatonin $(100 \mathrm{mg} / \mathrm{kg})$ may eliminate astrocytic swelling after SCI through down-regulating the expression level of GFAP protein. More studies are needed to analyze the possible therapeutic effects of melatonin on SCI patients.

\section{ACKNOWLEDGEMENT}

Author contributions: XL: manuscript writing; YW: data collection and data analysis; JY: data interpretation; YL: statistical analysis; DZ: literature search; MH, LX: study design.

Conflict of interest statement: None declared.

\section{REFERENCES}

1. Botterell EH, Jousse AT, Kraus AS, Thompson MG, WynneJones M, Geisler WO. A model for the future care of acute spinal cord injuries. Can J Neurol Sci 1975;2:361-80.

2. Kraus JF, Silberman TA, McArthur DL. Epidemiology of spinal cord injury. In: Principles of Spinal Surgery (Menezes AH, Sonntag VKH, Benzel EC, et al., eds). New York: McGraw-Hill, 1996; pp 41-58.

3. Staas WE, Formal CS, Freedman MK. Spinal cord injury and spinal cord injury medicine. In: Rehabilitation Medicine: Principles and Practice, 3rd edn (DeLisa JA, Gans BM, eds). Philadelphia: LippincottRaven, 1998; pp 1259-91.

4. Fujiki M, Furukawa $Y$, Kobayashi $H$, Abe T, Ishii K, Uchida Kamida T. Geranylgeranylacetone limits secondary injury, neuronal death, and progressive necrosis and cavitation after spinal cord injury. Brain Res 2005; 1053:175-84.

5. Leypold BG, Flanders AE, Burns AS. The early evolution of spinal cord lesions on MR imaging following traumatic spinal cord injury. AJNR Am J Neuroradiol 2008;29:1012-6.

6. Verkman AS, Ratelade J, Rossi A, Zhang H, Tradtrantip L. Aquaporin-4: orthogonal array assembly, CNS functions, and role in neuromyelitis optica. Acta Pharmacol Sin 2011;32:702-10.

7. Yang YB, Piao YJ. Effects of resveratrol on secondary damages after acute spinal cord injury in rats. Acta Pharmacol Sin 2011;24:703-10.

8. Bracken MB, Shepard MJ, Collins WF, Holford TR, Young W, Baskin DS, Eisenberg HM, Flamm E, Leo-Summers L, Maroon J. A randomized, controlled trial of methylprednisolone or naloxone in the treatment of acute spinal-cord injury. Results of the Second National Acute Spinal Cord Injury Study. N Engl J Med 1990;322:1405-11.

9. Bracken MB, Shepard MJ, Collins WF Jr, Holford TR, Baskin DS, Eisenberg HM, Flamm E, Leo-Summers L, Maroon JC, Marshall LF. Methylprednisolone or naloxone treatment after acute spinal cord injury: 1-year follow-up data. Results of the Second National Acute Spinal Cord Injury Study. J Neurosurg 1992;76:23-31.

10. Bracken MB, Shepard MJ, Hellenbrand KG, Collins WF, Leo LS Freeman DF, Wagner FC, Flamm ES, Eisenberg HM, Goodman JH. Methylprednisolone and neurological function 1 year after spinal cord injury. Results of the National Acute Spinal Cord Injury Study. J Neurosurg 1985;63:704-13.

11. Bracken MB, Shepard MJ, Holford TR, Leo-Summers L, Aldrich EF, Fazl M, Fehlings M, Herr DL, Hitchon PW, Marshall LF, Nockels RP, Pascale V, Perot PL Jr, Piepmeier J, Sonntag VK, Wagner F, Wilberger JE, Winn HR, Young W. Administration of methylprednisolone for 24 or 48 hours or tirilazad mesylate for 48 hours in the treatment of acute spinal cord injury. Results of the Third National Acute Spinal Cord Injury Randomized Controlled Trial. National Acute Spinal Cord Injury Study. JAMA 1997;277:1597-604.

12. Bracken MB, Shepard MJ, Holford TR, Leo-Summers L, Aldrich EF, Fazl M, Fehlings MG, Herr DL, Hitchon PW, Marshall LF, Nockels RP, Pascale V, Perot PL Jr, Piepmeier J, Sonntag VK, Wagner F, Wilberger JE, Winn HR, Young W. Methylprednisolone or tirilazad mesylate administration after acute spinal cord injury: 1- year follow up. Results of the Third National Acute Spinal Cord Injury Randomized Controlled Trial. J Neurosurg 1998;89:699-706. 
13. Pierrefiche G, Topall G, Courboin G, Henriet I, Laborit H. Antioxidant activity of melatonin in mice. Res Commun Chem Pathol Pharmacol 1993;80:211-23.

14. Tan DX, Chen LD, Poeggeler B, Manchester LC, Reiter RJ. Melatonin: a potent, endogenous hydroxyl radical scavenger. Endocr J 1993;1:5760.

15. Reiter RJ. Functional pleiotropy of the neurohormone melatonin: antioxidant protection and neuroendocrine regulation. Front Neuroendocrinol 1995;16:383-415.

16. Pierrefiche G, Topall G, Courboin G, Henriet I, Laborit H. Antioxidant effect of melatonin in mice. Res Commun Chem Pathol Pharmaco 1993;80:211-23.

17. Tan DX, Chen LD, Poeggeler B, Manchester LC, Reiter RJ. Melatonin: a potent, endogenous hydroxyl radical scavenger. Endocr J 1993;1:5760.

18. Reiter RJ, Melchiorri D, Sewerynek E, Poeggeler B, Barlow-Walden L, Chuang J, Ortiz GG, Acuña-Castroviejo D. A review of the evidence supporting melatonin's role as an antioxidant. J Pineal Res 1995;18:1 11

19. Oshio K, Binder DK, Yang B, Schecter S, Verkman AS, Manley GT. Expression of aquaporin water channels in mouse spinal cord. Neuroscience. 2004;127:685-93.

20. Saadoun S, Papadopoulos MC. Aquaporin-4 in brain and spinal cord oedema. Neuroscience. 2010;168:1036-46.

21. Wang X, Budel S, Baughman GG, Song KH, Strittmatter SM. Ibuprofen enhances recovery from spinal cord injury by limiting tissue loss and stimulating axonal growth. J Neurotrauma. 2009;26:81-95.

22. Xu GY, Liu S, Hughes MG, McAdoo DJ. Glutamate-induced losses of oligodendrocytes and neurons and activation of caspase- 3 in the rat spinal cord. Neuroscience 2008;153:1034-47.

23. Nesic O, Lee J, Ye Z, Unabia GC, Rafati D, Hulsebosch CE, Perez-Polo $J R$. Acute and chronic changes in aquaporin 4 expression after spinal cord injury. Neuroscience 2006;143:779-92.

24. Saadoun S, Bell BA, Verkman AS, Papadopoulos MC. Greatly improved neurological outcome after spinal cord compression injury in AQP4-deficient mice. Brain 2008;131:1087-98.

25. Lee JK, Kwak HJ, Piao MS, Jang JW, Kim SH, Kim HS. Quercetin reduces the elevated matrix metalloproteinases-9 level and improves functional outcome after cerebral focal ischemia in rats. Acta Neurochir 2011;153:1321-9.

26. Esposito E, Genovese T, Caminiti R, Bramanti P, Meli R, Cuzzocrea $\mathrm{S}$. Melatonin reduces stress-activated/mitogen-activated protein kinases in spinal cord injury. J Pineal Res 2009;46:79-86.

27. Liu JB, Tang TS, Yang HL, Xiao DS. Antioxidation of melatonin against spinal cord injury in rats. Chin Med J (Engl) 2004;117: 571-5.

28. Gül S, Celik SE, Kalayci M, Taşyürekli M, Cokar N, Bilge T. Dosedependent neuroprotective effects of melatonin on experimental spinal cord injury in rats. Surg Neurol 2005;64:355-61.

29. Fujimoto T, Nakamura T, Ikeda T, Takapi K. Potent protective effects of melatonin on experimental spinal cord injury. Spine 2000; 25:769-75.
30. Kaptanoglu E, Tuncel M, Palaoglu S, Konan A, Demirpençe E, Kilinç K. Comparison of the effects of melatonin and methylprednisolone in experimental spinal cord injury. J Neurosurg 2000;93:77-84.

31. Samantaray S, Sribnick EA, Das A, Knaryan VH, Matzelle DD, Yallapragada AV, Reiter RJ, Ray SK, Banik NL. Melatonin attenuates calpain upregulation, axonal damage and neuronal death in spinal cord injury in rats. J Pineal Res 2008;44:348-57.

32. Ray SK, Banik NL. Calpain and its involvement in the pathophysiology of CNS injuries and diseases: therapeutic potential of calpain inhibitors for prevention of neurodegeneration. Curr Drug Targets CNS Neurol Disord 2003;2:173-89.

33. Rowland JW, Hawryluk GWJ, Kwon B, Fehlings MG. Current status of acute spinal cord injury pathophysiology and emerging therapies: promise on the horizon. Neurosurg Focus 2008;25:E2.

34. Tator $\mathrm{CH}$, Fehlings MG. Review of the secondary injury theory of acute spinal cord trauma with emphasis on vascular mechanisms. J Neurosurg 1991;75:15-26.

35. Shepard MJ, Bracken MB. Magnetic resonance imaging and neurological recovery in acute spinal cord injury: observations from the National Acute Spinal Cord Injury Study 3. Spinal Cord 1999;37:8337.

36. Park K, Lee Y, Park S, Lee S, Hong Y, Kil Lee S, Hong Y. Synergistic effect of melatonin on exercise-induced neuronal reconstruction and functional recovery in a spinal cord injury animal model. J Pineal Res 2010;48:270-81.

37. Hsu MS, Seldin M, Lee DJ, Seifert G, Steinhäuser C, Binder DK. Laminar-specific and developmental expression of aquaporin-4 in the mouse hippocampus. Neuroscience 2011;178:21-32.

38. Tourdias T, Mori N, Dragonu I, Cassagno N, Boiziau C, Aussudre J, Brochet B, Moonen C, Petry KG, Dousset V. Differential aquaporin 4 expression during edema build-up and resolution phases of brain inflammation. J Neuroinflammation 2011;8:143.

39. Badaut J, Ashwal S, Obenaus A. Aquaporins in cerebrovascular disease: a target for treatment of brain edema. Cerebrovasc Dis 2011;31:521-31.

40. Hemley SJ, Bilston LE, Cheng S, Chan JN, Stoodley MA. Aquaporin-4 Expression in Post-Traumatic Syringomyelia. J Neurotrauma 2013;30:1457-67.

41. Kimura A, Hsu M, Seldin M, Verkman AS, Scharfman HE, Binder DK Protective role of aquaporin- 4 water channels after contusion spinal cord injury. Ann Neurol 2010;67:794-801.

42. Liang D, Bhatta S, Gerzanich V, Simard JM. Cytotoxic edema: mechanisms of pathological cell swelling. Neurosurg Focus 2007;22:E2

43. Marmarou CR, Liang X, Abidi NH, Parveen S, Taya K, Henderson SC, Young HF, Filippidis AS, Baumgarten CM. Selective vasopressin-1a receptor antagonist prevents brain edema, reduces astrocytic cell swelling and GFAP, V1aR and AQP4 expression after focal traumatic brain injury. Brain Res 2014;pii: S0006-8993(14)00792-6. 